\title{
A Critical Analysis on the Status of Child Labour in Western Odisha in India
}

\section{Samir Kumar Nanda}

Programme Manager-cum-Inspector, National Child Labour Project (Ministry of Labour E Employment, Govt. of India) Matha Sahi, PO/

Dist- Deogarh, Odisha, India

Corresponding author: drsamir.2015@gmail.com

Received: 12-04-2019

Revised: 21-07-2019

Accepted: 23-08-2019

\begin{abstract}
No civilised \& equitable society can tolerate the denial of their rights to its children \& lay claim to being called just "child labour", thus is a shur on all of us \& our sensitivity. Child labour is a very common global problem. Across the globe, to a lesser or greater degree, visible or invisible, admittedly or otherwise child labour exists. India is one of the examples of a nation plagued by the problem of child labour. From the time of independence, India has committed itself to be against child labour. In Western Odisha $79 \%$ of its population depends on agriculture and nearly $48 \%$ live below the poverty line. It is obvious that children are compelled to work in hazardous occupations and became vulnerable to occupational hazardous \& diseases. This article explain the magnitude, causes \& consequences of child labour and steps taken by the Government to eliminate child labour in Western Odisha. Here an effort has been made to analyse the status of child labours as well as other labours in Odisha. Identification of the area of concentration of child labour \& evaluations of dimensions of the problem has been made.
\end{abstract}

Keywords: Child labour, Western Odisha, population, agriculture

According to William Wordsworth "A Child is a Father of Man". To enable fathering of a valiant \& vibrant man, the child must be groomed well in the formative years of his life. Children constitute an integral part of the world populace. But their childhood has been challenged in many countries in several ways. Child labour is a problem of social concern. Its roots lie in poverty, unemployment, underemployment or low wages caused by inequitable distribution of resources, which are the characteristics of centralized and lopsided economy and the backward nature of agriculture.

Teaching the traditional trade or skill of the family to its children in the childhood itself has been a customary practice in India. In the primitive age, when man used to wander about in the forests in search of prey, he used to take his children along with him. In Gurukuls the children not only got education but also learnt how to become self-dependent. They ran small errands and participated in cleaning ashram, bringing water and served their preceptor. In farming too, the children lent some helping hands to their parents. But in those times, the children working in such a manner were not regarded as child labour and the work being done by them was a part of the normal process of experiencebased learning.

Consequent upon the industrial revolution, the practice of employing children as cheap labour along with the adult labour came into being. Gradually, the practice of engaging child labour became quite common. In some occupations, the work is entirely done by children.

\section{Definition}

The Child Labour (Prohibition and Regulation) Act, $1986^{1}$ defined child as labour who has not completed 
his 14 years of age. Whether part-time / full time in any occupation, engagement of child in the labour force simply means a complete or partial denial of childhood to him. He is not merely deprived of the jobs and carefree life of a child, but also of desirable mental and physical developments.

\section{Magnitude}

Table 1: Magnitude of Child Labour in India, Odisha \& Western Odisha

\begin{tabular}{llll}
\hline Census Year & India & Odisha & Western Odisha \\
\hline 1971 & $1,07,53,985$ & $4,92,477$ & $1,89,414$ \\
1981 & $1,36,40,870$ & $7,02,293$ & $2,70,112$ \\
1991 & $1,12,85,349$ & $4,52,394$ & $1,39,526$ \\
2001 & $1,25,91,667$ & $3,77,594$ & $1,09,276$ \\
2011 & $43,53,247$ & 92,087 & 75,440 \\
\hline
\end{tabular}

The table 1 shows the number of child labours detected in India, Odisha and Western Odisha during the census conducted in the year 1971, 1981, 1991, 2001 \& 2011. If we compare the above statistics we will find that in 1981 census maximum number of child labours identified at National level, State level and in Western Odisha also. If we go through the census report of 2011 we observe that the number of child labour has decreased in the country, Odisha and Western Odisha.

The table 2 indicates the number of child labours identified in the 10 Districts of Western Odisha during the year 1971, 1981, 1991, 2001 \& 2011 Decadal Census and 1997 \& 2005. District Level Child labour Survey conducted by the National Child Labour Project \& District Administration. If we observe the trend of the above figures, we will find that, the percentage of child labour decreased to $48 \%$ in the year 1991 in comparison to $1981,58 \%$ in 1997 survey in comparison to 1991 census and $49 \%$ in the 2011 census in comparison to 2005 survey. But during the rest of the survey period there is an increasing trend. In the 1981 census percentage increased up to $42 \%$ than in 1971, in 2001 census the figure again increased to $88 \%$ than 1997 survey and in 2005 survey it has been increased $37 \%$ in comparison to 2001 census.

\section{Western Odisha}

Western Odisha comprises of ten districts of Odisha State. The districts are Balangir, Bargarh, Boudh, Deogarh, Jharsuguda, Kalahandi, Nuapara, Sambalpur, Sonepur \& Sundargarh. In Western Odisha $79 \%$ of its population depend on agriculture and nearly $48 \%$ live below the poverty line. It is obvious that children are compelled to work in hazardous occupations and became vulnerable to occupational hazardous \& diseases.

The economic exploitation of children in Western Odisha has always been an area of concern. Most children work in highly exploitative conditions and all are deprived of even the most minimal educational facilities.

In the present study an effort has been made to analyse the status of child labours in the ten districts of Western Odisha. The study aims at identifying the area of concentration of child labour \& to evaluate dimensions of the problem. The causes \& consequences of the child labour problem has been studied. The main objective of this study is to find out the grass root reasons of the exploitation of children, cause of non-attending Primary Education and to find out how to overcome the problem.

In the whole Western Odisha area it is a fact that the child who does not attend formal schools is working as a child labour for Collection of water, fuel, household chores and taking care of younger siblings.

The study is conducted in the following areas of Western Odisha:

1. All the 10 districts of Western Odisha in brief.

2. All the 09 NCLP Offices of the Western Odisha.

Table 2: Magnitude of Child Labour in Western Odisha

\begin{tabular}{|c|c|c|c|c|c|c|c|}
\hline Survey Year & 1971 & 1981 & 1991 & 1997 & 2001 & 2005 & 2011 \\
\hline $\begin{array}{l}10 \text { districts of } \\
\text { Western Odisha }\end{array}$ & $1,89,414$ & $2,70,112$ & $1,39,526$ & 58,131 & $1,09,276$ & $1,49,299$ & 75,440 \\
\hline
\end{tabular}


3. One establishment from Deogarh District where maximum number of child labour are employed.

4. Two N.G.Os of Western Odisha.

5. Assistant Labour Commissioner, Bhawanipatna, District Labour Officers of Bargarh, Balangir, Boudh, Deogarh, Nuapara were interviewed.

6. Project Directors of National Child Labour Project of all the 09 Districts were interviewed.

7. Some of the Child Labour Students \& Parents on a random sampling basis were interviewed.

8. Eighty numbers of child labours of Subarnapur Districts rescued from two bricks kiln in Andhra Pradesh were interviewed.

\section{Findings}

Nearly $40 \%$ of the population of the region is autochthonous tribal or Adivasis and the rest belongs to general and other castes. The population of Western Odisha comprises $24.34 \%$ of the total population of Odisha state. Deogarh is the lowest irrigated district in the Western Odisha. However maximum number of villages are electrified in Balangir District is maximum and Deogarh district is in the lowest position. Deogarh District has the highest percentage of Child labour Population. Maximum percentage of child labour identified in the district of Deogarh whereas in Sundargarh District is the minimum.

\section{Poverty}

Due to family poverty cent per cent of the children are forced to join as child labour. About $92 \%$ of the child labour opined that if they will be rescued and rehabilitated in residential schools then they can be educated and can be able to join in the labour market as skilled labour to supplement the family income. Again they express that if they will be provided full meals for the day and rehabilitated away from the family members than they will not return to the works.

So far the reasons of child labour problem is concerned we see that $56 \%$ of child labour in Western Odisha \& $53 \%$ child labour of Deogarh District have opined that they joined work due to poverty and want of money. Again, 6.22\% child labour in Western Odisha \& 15.67\% in Deogarh District have stated that they joined work for all the below problems.

\section{Irregular Employment}

About $85 \%$ of parents say that if they will be provided with works on a regular basis then they will send their children to schools instead of sending them to works. They also stated that while they are migrated to the other states to earn living at that time the children are also accompanying them. In the neighbouring states as no facilities of study in the Oriya languages available therefore they forced to engage the children in the works to earn money.

About $70 \%$ of the families of respondents of Deogarh District belong to Daily wage \& agricultural labour classes whereas only 66,795 hector-cultivable lands are there in Deogarh district which is only $21 \%$ of the population. Again, only $24 \%$ of the said land is provided with irrigation facilities. So, $76 \%$ of the land remains uncultivated for six months in a year due to lack of irrigation. Therefore, the $70 \%$ of people who already depends upon agricultural employment do not get employment for the said periods. It is also found from the above table that irrigation facilities in Deogarh district are only $24 \%$, which is lowest in the Western Odisha.

As per the data collected from the report published by the Directorate of Economics \& Statistics, Odisha and G.M., DIC, Deogarh, there are only four small and medium scale industries established in Deogarh District with an employment of only 213 persons which is lowest in Western Odisha. This makes it clear that no such industrial employment is there in Deogarh district to provide people some sound incomes.

This is an important reason of child labour in the district. Because of large family size the parents are struggling to provide food, clothes and medicines to their children failing with the children are forced to join in the labour force.

\section{Living without parents}

From the study the researcher conclude that 35\% households have no fathers and $10 \%$ have no mothers. 
Because of which the children of these families are struggling for food.

\section{Large family size}

If we see the cases of Whole Western Odisha we find that $30 \%$ households have $5-6$ children $22 \%$ have $3-4$ children and $22 \%$ have more than 8 no. of children. If we calculate the data we see that $71 \%$ households have more than 5 children.

In Deogarh district out of 300 households interviewed about $150(50 \%)$ families have 5-6 no of children, 25\% cases have $7-8$ no. of children, $13 \%$ have more than 8 no. of children, $10 \%$ cases have 3-4 children and $2 \%$ have $1-2$ children. So, it is clearly seen from the table mentioned that $88 \%$ households have more than 5 no. of children.

\section{Illiteracy}

It is seen that only $38 \%$ of respondent fathers and $20 \%$ o respondent mothers are literate. So, illiteracy is also may be an important reason for which parents fail to realize the consequences of sending children to work.

It is also observed that $45 \%$ of parents in Western Odisha $\& 58 \%$ of parents in Deogarh District have studied up to middle standard only.

\section{Low Family income}

In case of Deogarh district, we will find that $50 \%$ respondent family has ₹ 600/- to ₹ 800 per month income, $40 \%$ have ₹ $800 /$ - to ₹ $600 /-$, $7 \%$ have ₹ $800 /-$ to ₹ $1000 /-$ and only $3 \%$ household's income is ₹ 1000/- and above per month. Therefore, the income of the individual household per month is very low. It is not possible to maintain a family with more than five children with such a low income.

\section{Debt}

Almost all the respondent households have indulged in debts in both Western Odisha and in Deogarh district. In Western Odisha the rate of debt is ₹ 10,000/- to ₹ 15,000/in $20 \%$ of households $19 \%$ have $₹ 5000 /$ - to ₹ $10,000 /$ - and only $11 \%$ have the range is above ₹ $20,000 /$ - per year. Only $15 \%$ households have the rate of debt is below ₹ 1000/- per annum.
Likewise, in Deogarh district 35\% of respondent families have maximum rate of debts i.e. above ₹ 20,000/- per year. Only $8 \%$ households have below ₹ 1000/- per year.

\section{Lack of Special Residential Schools for child labour}

It has become a problem for the labour officials to rehabilitate the rescued child labours. In maximum cases, the Labour Officials return the rescued child labours to their parents after filing cases against the employers and finally the child labours again return to the works after some days due to acute poverty. So in maximum cases the Labour Officials are unable to take action against such practices.

\section{Interference of Employer}

Employers disliked Labour Inspector visits and made the children run away as soon as they reached there for inspection. Employers did not allow them to interrogate child workers regarding age, hours of work, payment of wages etc.

\section{Hereditary Profession}

Hereditary professions have long played a significant role in the work of children in Western Odisha.

Having more no. of children, migration due to lack of works in the villages, alcoholism and bad habits of the elders, using of girl children to assist their mother at home and taking care of younger siblings, low wages, illiteracy of parents, inability of the sick \& unhealthy parents on feeding their children, severe economic problems, family debts, barren lands \& waste lands, high rate of interest on loans are also the reasons.

Broadly speaking some miscellaneous causes can be enlisted as follows:

1. Parents are lazy and interested to mange life from children earning.

2. The parents have no alternative entertainment after returning from hard work except sexual relation for relaxation which result maximum generation of family members.

3. Parents do not see any advantage in their children getting educated because they find educated 
persons wandering around, un-employed. In such a situation, they do not prepare themselves to send their children to school for getting education. The parents are also not able to encourage their children to get education.

4. The parents of the working children assume that the financial position of their family will improve, if the children work. Hence, they put their children to work at a very tender age.

5. Parents are unable to get full time employment and they do not get minimum wages. For such reasons the parents are forced to put their children to work.

6. The parents think that after all, their children will have to work when they grow up, the children will become very skilful, if they begin working during childhood. Parents cannot think of any alternative but for engaging their children in work.

7. Neither is proper guidance available to the parents nor they are motivated to improve the future of the children. They stake their children's future for the sake of a meagre immediate gain.

8. Some work depends upon the normal techniques, which is not possible in case of adult labour. These types of works can only be done perfectly by the child labour. For example:- Beedi Rolling.

9. A child labour works for much less wages than the adult labour.

10. The children have a great capacity of accomplishing a job smartly and speedily within the minimum time; the adult labour does not possess such qualities.

11. Children have the capacity to learn a job very fast and the employer derives benefit from this potential.

12. The children are less prone to addictions such as chewing betel, smoking beedies, taking tea etc. whereas adult labourers are generally habituated to such addictions owing to which they repeatedly take a break and thus neglecting their job. This leads to waste of time, which is not in the employer's interests.

13. The children do not get bored by performing monotonous jobs, whereas the adult labour is reluctant to do the same type of job continuously.

14. Owing to indifferent attitude of trade unions towards child labour, they become an easy prey for the employer for getting enormous amount of the work done from them.

15. Bonded labour system. The poor people of the village borrow money form the rich and engage the children of the family in the work of the rich people to repay the debt.

16. Alcoholism.

17. Lack of awareness.

18. Low implementation of child labour laws.

19. Vested interests of Administration.

20. Migration.

21. Age detection.

22. If the mother works as servant in others houses and if the child of the said mother is a girl and if after returning from the school she has to finish all the works/tasks (both in outside and inside home) of the mother in the house than we see that she has to take the burden of both study and works. In such cases, the said child prefers to work only and discontinue the study.

\section{Suggestions}

1. A committee should be constituted in the village level involving Higher Officers, Teachers and Educated mass and responsibility should be given to them. The Committee shall work once in a week (on holiday or Govt. shall give them holiday) the following tasks:-

(a) The Committee will sort out the grievance/ problems of the people.

(b) The Committee takes necessary step to communicate all the beneficiary schemes of the Govt. at the grass root level.

(c) The Committee will help to remove all the obstacles regarding sending children to schools.

(d) Help the people for providing bank loans. 
(e) Help the people to repay the loans.

(f) Help the people for Birth Registration Certificate.

(g) Help the people for the economical developments.

(h) The Committee will regularly observe whether the parents sending children to school or not.

(i) The Committee will punish the families (Both financial \& Physical) who will not send children to schools.

(j) The Committee also supervises whether the Line Govt. Officials are doing their duty for the better enrolment of children or not. And report the govt.

(k) The Committee also makes surprise checking whether the Labour Officials are inspecting the establishments properly or not and whether the Officials are taking action impartially or not.

2. The children should be freed from family at an age limit like the foreign countries.

3. Residential schools with joyful learning, all facilities, Vocational training, Games and earning facilities within the school should be introduced. The money should be sent to the parents. As a result of which all the parents will be encouraged to send their children to the school instead of work. The children will help the profession of parents. Skill development can be done.

4. Due to absence of immediate rehabilitation, the Child labour Act, cannot be properly implemented. Again, if the rescued child labour will free for one day then he/she will join another establishment. Therefore, immediate rehabilitation facilities should be started.

5. Common man cannot afford the high market price of sugar, oil, dal etc. Only rice @₹1/- cannot manage the family. They are poor as they cannot compete the general people and owner .So supplementary income should be encouraged.

6. After the marriage the daughter the parents should follow up the financial conditions of the family of daughter, if required.

\section{Remedies}

1. Article-24 of the Indian Constitution should be amended immediately. Employment of children in any occupations, processes should be prohibited strictly.

2. Prevention is better than cure. The implementation of related laws should so strict that no employer dares to employ children under any circumstances.

3. Identification of child labour should be done properly through door to door survey with responsible \& outside agency of the district so as no single child labour should be left out and immediate action should be taken against the defaulted person on the spot.

4. Like Census work responsible shall be fixed for the persons engaged in identification works and disciplinary action shall be taken against the defaulter staff.

5. In maximum cases as per the statistics of SSA all the students are enrolled in their attendance registers since years but in actual cases they do not go to school rather they work as labour in the grass root level. They should be vigilantly identified .The Compulsory Education Act should be implemented strictly. If any false entries are found in any schools than immediate action shall be taken against the concerned teacher/staff.

6. The poverty alleviation programme of the Govt. is meant for the BPL people. But in physical, some of the APL people have included politically instead of the BPL people like RSBY. So, this procedure should be immediately rectified.

7. While the Inspector of the Labour Department inspects the establishment the age of the child labour creates problem. As per the act in order to finalise the age of the concerned child labour both the employer \& child labour have to go to the Certifying Surgeon for examination who works at more than $100 \mathrm{~km}$ away. This point should be amended immediately. The Inspectors should be empowered to detect \& finalise the age on the spot. The Inspector should also be empowered to take action against the defaulted employer on the spot. 
8. In some practical cases the Labour Officials suppress the actual facts by taking bribes from the employer of the child labour. If such cases are found than the concerned Officials should be punished.

9. Maximum Poverty alleviation schemes and beneficiary schemes of the Govt. are applicable for the SC, ST and backward class people. No such scheme has yet been prepared for the general classes. However some of the child labours are also found from the general poor classes. Even child labours are also found in Brahmin family and no such scheme till date has been prepared by the Govt. for the said classes. So, some anti poverty schemes should also be designed for the said people. Because all the SC, ST and BC classes are not poor nor all the General Classes are rich. Such types of discriminations should be eliminated.

10. As per the Child Labour Act employment of child labour is a punishable offence in all cases except in case of home workers and where the father, mother etc., are employers. In this point maximum employers escape. For example in 1997 District Level Survey 498 no of child labours were identified in 37 no Beedi Rolling establishments in Deogarh district which is completely hazardous. .But, all the employers of the 37 establishments had been escaped by showing all the 498 child labours as home workers and helping their parents. This part of the act should be amended and law should be designed in such a way that every person who engaged child labour should be punished.

11. All the children out of schools are child labours \& child labour system is a part of the village life. If the children will not work than where they will go? The answer is "School". This opinion is taken in the western countries. But, in India child labour is prohibited in factories not in agriculture. There is no such discipline in India regarding going to school and no body mentally hurt if a child does not go to school. Non-economic causes like sending children to schools in spite of poverty; to create a favourable environment regarding sending children to schools, to convince the parents and qualitative education are also equally important. Those children who are both working and studying are taking double burdens of work and study, in such cases children prefer to only work and discontinue their study. The poor people should be united and favourable mentality should be shown for their rights. Liasioning between Society and Govt. will give maximum profits. Child rights are such a problem, which can be acceptable by all, and a common understanding should be done. The parents should consider sending children as duty.

12. The Govt. aid for the development of the children and their family should be properly invested.

13. Family planning should be encouraged among the villagers.

14. The per head income should be enhanced.

15. The bad habits of the parents must be discouraged.

\section{CONCLUSION}

The time has come to realize the seriousness of the child labour. Keeping this in mind, all the individual citizens, labour forums, NGOs and all the lying departments of the Government should work jointly and take the responsibility to make the country shine in all aspects. To eliminate child labour from human society the social reformers, administrators and policy makers with combine efforts should discharge their responsibilities and duties. There are a host of complex issues which need to be vigorously pursued to face the challenge head-on.

\section{END NOTES}

${ }^{1}$ The Child Labour (Prohibition and Regulation) Act, 1986.

\section{REFERENCES}

1. Gagan, Vishal. 2005. Child Labour. SRADHA, Vol-1, Sambalpur, Odisha, NCLP.

2. Karthikeyan, Sujata 2007. Chairman's Desk. Prayas, IV $^{\text {th }}$ edition, Cuttack, Odisha, NCLP.

3. Manual for Implementation of NCLP. 2006. New Delhi.

4. Ministry of Labour \& Employment, Government of India.

5. Nanda, Dr. Samir Kumar. 2017. Labour Scenario in Odisha. Odisha Review, LXXIII(10), I\& PR. Department, Govt. of Odisha 


\section{$\mathcal{D}$ Nanda}

6. Nanda, Dr. Samir Kumar. 2016. Give My Childhood. Bhubaneswar, Publishing House.

7. Orissa reference Annual. 2009. Geography of Orissa, Bhubaneswar.

8. Information \& Public Relation Department, Govt. Of Orissa.

9. Sekar, Dr. Helen, R. 2015. The Child Labour (P\&amp; R)Act, 1986 \& its Implementation, Noida, VVGNLI.
10. www.labour.gov.in-schemes-child labour-census data

11. www.labdirodisha.gov.in-child labour

12. www.labdirodisha.gov.in-sli

13. www.vvgnli.gov.in

14. www.wcdodisha.gov.in/child welfare/oscps 